\title{
PENGARUH KOMITMEN PEGAWAI TERHADAP DISIPLIN KERJA PADA PT. KERETA API INDONESIA (PERSERO) TANJUNG KARANG
}

\author{
A. Choiri Febriansyah ${ }^{(1)}$, Abdul Naser ${ }^{(2)}$, Raditte Husin ${ }^{(3)}$ \\ Fakultas Ekonomi Universitas Sang Bumi Ruwa Jurai \\ ahmad.choirifebri@gmail.com,abdul.naser@fe.saburai.ac.id,raditte.husin@fe.saburai.ac.id
}

\begin{abstract}
Abstrak. Permasalahan yang dihadapi pada penelitian ini ada pengaruh komitmen pegawai terhadap disiplin kerja, sedangkan tujuan dari penelitian ini adalah untuk mengetahui pengaruh komitmen pegawai terhadap disiplin kerja. Metode yang digunakan adalah metode analisis kualitatif dan analisis kuantitatif. Berdasarkan hasil uji hipotesis yang penulis lakukan melalui analisis regresi linier sederhana diperoleh persamaan dimana $t_{\text {hitung }}$ untuk Komunikasi sebesar 28.831 sedangkan $t_{\text {tabel }}$ sebesar dengan dk (30-2 - 28) adalah 1.688, jadi $t_{\text {hitung }}$ $28.831>\mathrm{t}_{\text {tabel }} 0.05(30-2=28)=1-688$, sehingga dapat diketahui bahwa Komitmen pegawai berpengaruh positip signifikan terhadap disiplin kerja pegawai PT. Kereta Api Indonesia (Persero) Tanjung Karang, selain itu semakin baik komitmen pegawai yang dilakukan maka disiplin kerja pegawai dalam berkerja akan semakin baik sehingga berdampak kepada kemajuan dan kualitas sumber daya manusia. Sedangkan dari hasil nilai Koefesien Determinasi ( $R$ Square) diperoleh nilai sebesar 0.979 atau secara statistik 97.9\% komitmen pegawai PT. Kereta Api Indonesia (Persero) Tanjung Karang dipengaruhi oleh disiplin kerja pegawai. Sedangkan sisanya $(100 \%-97.9 .6 \%)=2.1 \%$ Disiplin kerja pegawai PT Kereta Api Indonesia (Persero) Tanjung Karang dipengaruhi oleh faktor-faktor lain selain variabel yang sedang teliti.
\end{abstract}

Kata kunci: Disiplin, Komitmen, Kerja, Pegawai.

\section{PENDAHULUAN}

Manajemen sumber daya manusia memegang peranan yang sangat penting untuk kemajuan suatu organisasi. Sumber daya manusia yang berkompeten memegang peranan penting untuk Pegawai Negeri Sipil dikarenakan seleksi Pegawai Negeri Sipil melalui tahap-tahap seleksi tes yang ketat dan tidak semua orang dapat lolos. Pegawai Negeri Sipil (PNS) menurut UU No.43/1999 pasal 1 adalah keseluruhan upaya untuk meningkatkan efisiensi, efektifitas, dan derajat profesionalisme penyelenggaraan tugas, fungsi, dan kewajiban kepegawaian yang meliputi perencanaan, pengadaan,pengembangan kualitas, penempatan, promosi, penggajian, kesejahteraan, dan pemberhentian (Nenny Anggraeni, 2011).

Sehubungan dengan undang-undang tersebut Pegawai Negeri Sipil sebagai aparat pemerintah yang mempunyai peran penting untuk negara dan sebagai tulang punggung negara diharapkan dapat menciptakan keberhasilan pembangunan nasional,sehingga dapat mewujudkan kemakmuran masyarakat dengan kinerja nya yang baik. Seperti halnya dengan Kementerian Perhubungan PT Kereta Api Indonesia (Persero) Tanjung Karang Bandar Lampung yang juga berusaha untuk meningkatkan kinerja PNS nya Komitmen organisasi dan disiplin kerja yang dialami oleh pegawainya.

Komitmen organisasi memiliki arti penerimaan yang kuat dalam diri individu terhadap tujuan dan nilai-nilai perusahaan, sehingga individu tersebut akan berkarya serta memiliki hasrat yang kuat untuk tetap bertahan di perusahaan (Khaerul Umam, 2010). Terdapat 3 dimensi komitmen organisasi (Arfan Ikhsan, 2015) yaitu Komitmen afektif (Affective commitmen), 
Komitmen berkelanjutan (Continuance cimmitmen), dan Komitmen normatif (Normative commitmen).

Komitmen organisasi menjadi hal yang penting bagi sebuah organisasi. Allen and Mayer dalam Darwish (2000) menyatakan komitmen organisasi sebagai perasaan karyawan untuk wajib tinggal dengan organisasi, perasaan yang dihasilkan dari internalisasi tekanan normatif diberikan pada seorang individu sebelum masuk atau setelah masuk.

Disiplin kerja menunjukkan sejauh mana seseorang individu mampu menjalankan peraturan yang telah ditetapkan ditempat mereka bekerja. Disiplin yang baik mencerminkan besarnya tanggung jawab seseorang terhadap tugas yang diberikan kepadanya. Suryohadiprojo dalam Fadilla (2002), menyatakan bahwa disiplin adalah kesadaran bahwa tanpa didasari unsur ketaatan, tujuan organisasi tidaklah tercapai. Jadi disiplin merupakan kunci untuk tercapainya tujuan suatu organisasi, sehingga disiplin kerja harus diperhatikan oleh pihak organisasi.

Ada beberapa hal yang dapat mempengaruhi disiplin kerja, salah satunya adalah kepuasan kerja, Maryadi (2012), dimana tenaga kerja yang puas akan memiliki sikap positif dengan pekerjaannya sehingga memacu kinerjanya dan otomatis disiplin kerjanya baik.

Menurut Moenir dalam Irawati dan Mustakim, ada 2 jenis disiplin yang sangat dominan yaitu disiplin dalam hal waktu dan disiplin dalam hal kerja atau perbuatan. Keduanya merupakan kesatuan yang tak dapat dipisahkan dan saling mempengaruhi. Pada dasarnya seseorang dalam bekerja akan merasa nyaman dan tinggi kesetiaannya pada perusahaannya jika dalam bekerjanya memperoleh kepuasan kerja. Kepuasan adalah sesuatu perasaan dimana seseorang mendapatkan apa yang diharapkan atau bahkan melebihi apa yang diharapkan, sedangkan kerja merupakan usaha seseorang untuk mencapai tujuan dengan memperoleh imbalan atau gaji dari kontribusinya kepada tempat pekerjaannya (Koesmono, 2005).

Kinerja pegawai sangat dipengaruhi oleh komitmen kerja dan disiplin kerja pegawai. komitmen kerja yang profesional adalah sebuah rute kunci menuju jalan keberhasilan. Tanpa dilumuri oleh komitmen kerja yang penuh profesionalisme, kita mungkin akan mudah tergelincir menjadi barisan para pecudang. Tanpa kesadaran batiniah untuk menjejakkan komitmen kerja yang profesionalisme dalam segenap raga, kita mungkin akan segera menjadi insan-insan yang gagap dengan dinamika perubahan.

Miskin prestasi, dan absen dari perjalanan panjang menuju manusia produktif, mulia nan bermartabat. Salah satu sikap yang mendukung kepada komitmen kerja yang tinggi adalah disiplin kerja. Disiplin kerja dibicarakan dalam kondisi yang seringkali timbul bersifat negatif. Disiplin lebih dikaitkan dengan sanksi atau hukuman.

Disiplin dalam arti positif seperti yang dikemukakan oleh Hodges dalam Helmi (2002) mengatakan bahwa: "Disiplin dapat diartikan sebagai sikap seseorang atau kelompok yang berniat untuk mengikuti aturan-aturan yang telah ditetapkan." Dalam kaitannya dengan pekerjaan, pengertian disiplin kerja adalah suatu sikap dan tingkah laku yang menunjukan ketaatan aparat pemerintahan atau karyawan terhadap peraturan organisasi.

Apabila aparat pemerintahan sudah bisa membiasakan diri untuk disiplin dalam segala hal maka setiap pekerjaan yang dilakukan pasti akan cepat beres dan tertata dengan baik sehingga secara tidak langsung akan meningkatkan komitmen kerja yang baik. Dengan disiplin kerja yang bagus, setiap aparat pemerintahan akan selaku menjaga pekerjaannya dengan baik dan tidak akan membiarkan pekerjaannya 
terbengkalai. Dengan penerapan sikap seperti ini, maka pelayanan kepada masyarakat akan memuaskan sehingga masyarakat akan merasa terbantu sekali dalam mengurusi keperluan mereka yang berhubungan dengan pelayanan yang diberikan.

Apabila seorang pegawai pemerintahan mempunyai komitmen kerja dan disiplin kerja yang tinggi maka akan berdampak positif pada kinerja pegawai tersebut. Maksudnya adalah bahwa kinerja pegawai akan berjalan sesuai dengan tujuan yang diharapkan karena komitmen kerja dan disiplin kerja sudah diterapkan sehingga setiap pekerjaan akan dilaksanakan dengan efektif dan efisien.

Persoalan-persoalan yang muncul dalam organisasi kerja salah satunya adalah bahwa organisasi kerja yang ada pada PT. Kereta Api Indonesia (Persero) Tanjung Karang Bandar Lampung menghadapi masalah berkaitan dengan komitmen kerja dan disiplin pegawai PT. Kereta Api Indonesia (Persero) Tanjung Karang Bandar Lampung.

Masih adanya karyawan yang mempunyai komitmen kerja yang rendah disebabkan kurangnya komunikasi yang dibangun antara atasan dan bawahan sehingga komitmen kerja hanya slogan bagi sebagian karyawan PT. Kereta Api Indonesia (Persero) Tanjung Karang Bandar Lampung. Selain itu masih adanya pegawai PT Kereta Api Indonesia (Persero) Tanjung Karang yang tidak disiplin pada pekerjaan dengan adanya beberapa karyawan yang mangkir dari pekerjaan.

Berdasarkan hasil penelitian awal diketahui tingkat kemangkiran pegawai PT. Kereta Api Indonesia (persero) Bandar Lampung periode Januari s.d. Mei 2016 untuk tidak masuk karena izin ada 32 orang, tidak masuk karena sakit ada 25 orang dan tidak masuk tanpa keterangan ada 20 orang dengan jumlah tingkat kemangkiran pegawai PT. Kereta Api
Indonesia (Persero) Bandar Lampung priode Bulan Januari s.d Mei 2016 berjumlah 67 pegawai.

Berdasarkan uraian tersebut peneliti tertarik untuk meneliti lebih lanjut dengan judul: "PENGARUH KOMITMEN PEGAWAI DI TERHADAP DISIPLIN KERJA PADA PT KERETA API INDONESIA (PERSERO) TANJUNG KARANG BANDAR LAMPUNG",

\section{KAJIAN TEORI}

\section{Pengertian Komitmen}

Ketika perusahaan menawarkan pekerjaan dan pelamar kerja menerima tawaran tersebut, pelamar kerja tersebut telah menjadi bagian dari perusahaan. Dengan menjadi bagian dari perusahaan, karyawan dididik untuk berkomitmen pada tujuan perusahaan. Ada banyak alasan mengapa sebuah organisasi harus berusaha meningkatkan komitmen organisasi para karyawannya. Sebagai contoh banyak penelitian menemukan bahwa semakin karyawan berkomitmen kepada perusahaan, karyawan tersebut akan berusaha lebih baik dalam menyelesaikan tugas-tugasnya.

Selain itu, karyawan yang berkomitmen juga akan meningkatkan produktivitas para karyawan karena karyawan merasa menyatu dengan perusahaan dan bekerja untuk mencapai tujuan perusahaan. Dengan adanya rasa menyatu dengan perusahaan, karyawan tidak berpikir untuk meninggalkan perusahaan sehingga dikatakan komitmen organisasi yang tinggi akan menurunkan keinginan untuk pindah para karyawan (Richard M. Steers dan Lyman W. Porter, 2001).

Ada berbagai macam defenisi yang dikemukakan oleh para ahli mengenai komitmen karyawan terhadap organisasi. Steers \& Porter (2004) mendefinisikan komitmen organisasi sebagai identification 
(kepercayaan terhadap nilai-nilai organisasi), job involvement (kesediaan untuk berusaha sebaik mungkin demi kepentingan organisasi), dan loyalty (keinginan untuk tetap menjadi anggota organisasi bersangkutan) yang dinyatakan oleh seorang karyawan terhadap organisasinya. Komitmen organisasi artinya lebih dari sekedar keanggotaan formal, karena meliputi sikap menyukai organisasi dan kesediaan mengusahakan tingkat upaya yang tinggi bagi kepentingan organisasi tercakup unsur loyalitas terhadap organisasi, keterlibatan dalam bekerja, dan identifikasi terhadap nilainilai dan tujuan organisasi.

Komitmen organisasi didefinisikan sebagai derajat dimana karyawan terlibat dalam organisasinya dan berkeinginan untuk tetap menjadi anggotanya, dimana didalamnya mengandung sikap kesetiaan dan kesediaan karyawan untuk bekerja secara maksimal bagi organisasi tempat karyawan tersebut bekerja (Greenberg dan Baron, 2003). Menurut Daft (2003) komitmen organisasi merupakan sikap penting yang mempengaruhi kinerja.

Daft (2003) mendefinisikan komitmen organisasi sebagai loyalitas dan keterlibatan yang tinggi pada organisasi. Karyawan dengan derajat komitmen organisasi yang tinggi akan melibatkan dirinya pada organisasi dan bekerja atas nama organisasi. Sedangkan menurut Blau dan Boal dalam Sopiah (2008) menyebutkan komitmen organisasional sebagai keberpihakan dan loyalitas karyawan terhadap organisasi dan tujuan organisasi.

\section{Faktor-faktor yang Mempengaruhi Komitmen}

Banyak penelitian yang dilakukan untuk mengetahui faktor-faktor yang mendukung dan memperkuat komitmen organisasi karyawan dalam mancapai tujuan organisasi, diantaranya adalah penelitian Mowday (dalam Greenberg \& Baron, 2002) mengelompokkan empat faktor besar yang mempengaruhi komitmen organisasi, yaitu :

1. Karakteristik personal, antara lain usia, lama kerja, tingkat pendidikan, jenis kelamin, ras, dan beberapa faktor kepribadian lainnya. Secara umum, usia dan lama bekerja mempunyai hubungan positif dengan komitmen organisasi. Sementara tingkat pendidikan mempunyai hubungan negatif dengan komitmen organisasi, meskipun hubungan ini tidak terlalu konstan. Wanita cenderung memiliki komitmen organisasi yang lebih tinggi daripada pria. Beberapa karakteristik kepribadian lain seperti motivasi berprestasi dan perasaan kompeten ditemukan berhubungan dengan komitmen organisasi.

2. Karakteristik pekerjaan dan peran, antara lain kesempatan kerja, konflik peran dan ambiguitas peran. Semakin besar kesempatan yang diperoleh dalam bekerja semakin banyak pengalaman yang diperolah yang pada akhirnya memperbesar komitmen individu terhadap organisasi. Sedangkan konflik peran mempunyai hubungan yang negatif dengan komitmen terhadap organisasi, demikian halnya dengan ambiguitas peran.

3. Karakteristik struktural organisasi, antara lain ukuran organisasi, kesatuan, luasnya kontrol dan sentralisasi otoritas.

4. Pengalaman kerja, antara lain ketergantungan pada organisasi, kepentingan personal pada perusahaan, sikap positif terhadap perusahaan, dan keterikatan sosial individu dalam perusahaan. Semakin besar semua faktor tersebut semakin tinggi pula komitmen individu terhadap organisasi. 
5. Dukungan organisasi ini didefinisikan sebagai sejauh mana pegawai mempersepsikan bahwa organisasi (lembaga, atasan, dan rekan kerja) memberi dorongan, respek, menghargai kontribusi pegawai, dan memberi apresiasi bagi individu dalam pekerjaannya. Pack dan Soetjipto (2005) menyatakan bahwa persepsi karyawan terhadap dukungan organisasi mempunyai hubungan yang positif komitmen organisasi. Hal ini berarti jika organisasi peduli dengan keberadaan dan kesejahteraan personal karyawan dan juga menghargai kontribusi karyawan pada organisasi maka karyawan mau mengikatkan diri dan menjadi bagian dari organisasi.

\section{Pengertian Disiplin Kerja}

Disiplin kerja adalah suatu bentuk tindakan manajemen untuk menengakkan standar-standar organisasi (Davis \& Newstrom, 2006). Hal serupa juga dikemukakan oleh Gibson (dalam Hapsari, 2007) bahwa disiplin adalah penggunaan beberapa hukuman atau sanksi jika karyawan menyimpang dari peraturan. Disiplin (discipline) adalah bentuk pengendalian diri karyawan dan pelaksanaan yang teratur dan menunjukkan tingkat kesungguhan tim kerja dalam suatu organisasi (Simamora, 2003).

Menurut Nitisemito (2002) bahwa kedisiplinan bukan hanya menyangkut masalah kehadiran yang tepat waktu di tempat kerja namun lebih tepat diartikan sebagai suatu sikap, tingkah laku, dan perbuatan yang sesuai dengan peraturan dari perusahaan baik tertulis maupun tidak. Jadi, kedisiplinan dalam suatu perusahan dapat ditegakkan bilamana sebagian besar peraturan-peraturannya ditaati oleh sebagian besar karyawan.

Disiplin kerja akan membawa dampak positif bagi karyawan maupun organisasi.
Disiplin yang tinggi akan membuat karyawan bertanggungjawab atas semua aspek pekerjaannya dan meningkat kan prestasi kerjanya yang berarti akan meningkatkan pula efektivitas dan efisiensi kerja serta kualitas dan kuantitas kerja.

Disiplin adalah kesadaran dan kesediaan seseorang menaati semua peraturan perusahaan dan norma-norma sosial yang berlaku. Adapun arti kesadaran adalah sikap seseorang yang secara sukarela menaati semua peraturan dan sadar akan tugas dan tanggung jawabnya. Sedangkan kesediaan adalah suatu sikap, tingkah laku dan perbuatan seseorang yang sesuai dengan peraturan perusahaan baik yang tertulis maupun tidak (Hasibuan, 2005).

Siswanto (dalam Hapsari, 2004) disiplin adalah suatu sikap menghormati, menghargai, patuh dan taat pada peraturanperaturan yang berlaku baik yang tertulis maupun tidak tertulis serta sanggup menjalankan dan tidak mengelak untuk menerima sanksi-sanksinya apabila ia melanggar tugas dan wewenang yang diberikan kepadanya.

\section{Faktor-faktor yang Mempengaruhi Disiplin Kerja}

Faktor-faktor yang mempengaruhi disiplin kerja secara umum dapat dibedakan menjadi dua yaitu faktor dari dalam individu dan faktor dari luar individu. Faktor dari dalam individu meliputi : kepribadian, semangat kerja, motivasi kerja intrinsik serta kepuasan kerja. Sedangkan faktor dari luar individu meliputi : motivasi kerja ekstrinsik, kepuasan kerja, kepemimpinan, lingkungan kerja dan tindakan indisipliner yang diberikan. Kepribadian dari para karyawan menentukan perilaku disiplin kerja.

Yuspratiwi (2002), menemukan bahwa individu yang memiliki locus of control internal lebih mampu mengontrol waktunya, lebih bersungguh-sungguh 
dalam bekerja dan lebih menunjukkan performansi kerja yang lebih baik pada situasi yang kompleks. Selain itu faktor kepribadian juga akan berpengaruh pada persepsi karyawan terhadap gaya kepemimpinan atasan, bagaimana atasan memperlakukan karyawannya akan dinilai secara langsung oleh karyawan. Persepsi tersebut dapat mempengaruhi performansi kerja seseorang, dalam hal ini disiplin kerja diri karyawan

Motivasi kerja dan kepuasan kerja dimasukkan sebagai faktor dari dalam diri individu dan faktor dari luar individu. Motivasi kerja intrinsik dalam hal ini yaitu adanya perasaan bangga dari dalam diri individu terhadap pribadi dan organisasi tempat dia bekerja sehingga hal ini akan membangun kepercayaan diri karyawan, karyawan sendiri akan secara sukarela melaksanakan apa yang menjadi kewajibannya di perusahaan tersebut.

Sedangkan untuk motivasi kerja ekstrinsik yaitu adanya penghargaan dan pujian dari atasan, hal ini bisa dijadikan sebagai reward untuk bekerja lebih baik. Penghargaan dan pujian tersebut akan mendorong karyawan untuk bekerja secara maksimal dengan memperhatikan ketentuan-ketentuan dan aturan-aturan yang berlaku di dalam perusahaan

Kepuasan kerja sendiri juga mempengaruhi disiplin kerja seorang karyawan. Kepuasan kerja yang berasal dari dalam diri individu yaitu arti dari pekerjaan itu sendiri bagi karyawan. Dengan adanya kepuasan kerja yang tumbuh dalam diri individu membuat karyawan lebih giat bekerja secara suka rela tanpa adanya paksaan.

Sedangkan yang merupakan faktor dari luar individu berupa gaji yang cukup maka akan mendorong karyawan untuk meningkatkan disiplin kerjanya. Faktor lain yang merupakan faktor dari luar individu berupa kepemimpinan, dimana keteladanan pimpinan mempunyai pengaruh yang sangat besar dan memberi efek yang positif dalam menengakkan disiplin.

Ketika karyawan dituntut untuk menaati peraturan maka pimpinan diharapkan juga mentaati peraturan yang berlaku. Ketaatan pimpinan ini akan menjadi contoh untuk diikuti karyawan (Nitisemito,2002:23). Lingkungan kerja juga berpengaruh terhadap perilaku disiplin kerja. Lingkungan kerja yang berpengaruh pada perilaku disiplin kerja dapat dikatakan sebagai lingkungan dalam organisasi yang menciptakan lingkungan cultural dan sosial tempat berlangsungnya kegiatan organisasi.

Tindakan indisipliner bukan sematamata berupa hukuman tetapi lebih ditekankan agar karyawan melakukan kebiasaan yang dianggap baik oleh perusahaan. Hal ini bisa menjadi pendamping peningkatan kesejahteraan sehingga diharapkan pencapaian disiplin akan lebih berhasil (Nitisemito, 2002). Penegakan disiplin/ tindakan indisipliner dapat dibagi menjadi dua yaitu positif dan negatif. Tindakan disiplin positif adalah dengan diberi nasehat untuk kebaikan dimasa yang akan datang.

\section{METODE PENELITIAN}

\section{Objek Penelitian}

Adapun objek penelitian ini adalah PT Kereta Api Indonesia (Persero) Tanjung Karang Bandar Lampung Jalan Teuku Umar No 23 penelitian ini dilakukan dari bulan Juni 2016 hingga Agustus 2016.

\section{Metode dan Teknik Pengumpulan Data}

Metode yang digunakan dalam penelitian ini adalah metode deskriftif kuantitatif yaitu metode penelitian yang berupa fakta statistik dengan menggunakan angka.

Dalam penelitian ini jenis data yang diperlakukan adalah : 
a. Data Primer

Data primer merupakan data dasar yang akan diperoleh langsung tanpa perantara orang atau lembaga lain sebagai pihak ketiga. Data primer ini diperoleh dengan wawancara melalui responden dengan menggunakan daftar pertanyaan.

b. Data Sekunder

Data skunder merupakan data yang diperoleh melalui orang lain yang berhubungan dengan permasalahan yang dipecahkan. Data sekunder ini diperoleh melalui cara studi dokumenter yaitu mengumpulkan dan mempelajari brosurbrosur serta dokumen organisasi.

\section{Sampel dan Populasi}

Berdasarkan pendapat Suharsimi Arikunto (2010) menyatakan bahwa apabila subjeknya kuarng dari 100 lebih baik diambil semua, tetapi apabila subjek lebih dari 100 maka dapat diambil 10\%$15 \%$ atau $15 \%-25 \%$, sehubungan populasi dalam penelitian ini berjumlah 188 maka sampel dalam penelitian ini ditentukan $16 \%$ dari jumlah populasi. Jadi sampel dalam penelitian ini adalah $188 \times 16 \%=30$ orang pegawai.

\section{Metode Analisis Data}

Metode analisis data yang digunakan dalam penelitian ini adalah metode analisis kuantitatif dengan rumus Regresi Linier Sederhana :

$$
Y=a+b X+e
$$

Keterangan:

$\mathrm{Y}=$ Disiplin kerja

$\mathrm{a}=$ Konstanta

$\mathrm{b}=$ Koefisien regresi $\mathrm{X}$

$\mathrm{X}=$ Komitmen pegawai

$\mathrm{e}=$ Faktor kesalahan
Untuk mengetahui besarnya pengaruh, penghitungan koefisien korelasi tersebut kemudian dilanjutkan dengan Rumus Koefisien Determinasi atau Koefisien Penentu (KP):

$$
K P=(r)^{2} x 100 \%
$$

Untuk menguji secara hipotesis secara parsial digunakan Uji t dengan rumus :

$$
t_{\text {hitung }}=\frac{r \sqrt{N-2}}{\sqrt{1-r^{2}}}
$$

Keterangan:

$$
\begin{array}{ll}
\mathrm{t}_{\text {hitung }} & =\text { Nilai } \mathrm{t} \\
\mathrm{r} & =\text { Koefisien Korelasi } \\
\mathrm{N} & =\text { Jumlah responden }
\end{array}
$$

Kriteria untuk Uji $\mathrm{t}$ adalah sebagai berikut :

a. Apabila nilai $t_{\text {hitung }}<\mathrm{t}_{\text {tabel }}$ atau $\rho<0,05$, maka Ho diterima dan Ha yang berarti variabel independen tidak berpengaruh secara signifikan terhadap variabel dependen.

b. Apabila nilai $\mathrm{t}_{\text {hitung }}>\mathrm{t}_{\text {tabel }}$ atau $\rho>0,05$ maka Ho ditolak dan Ha diterima yang berarti variabel independen berpengaruh secara signifikan terhadap variabel dependen.

\section{HASIL DAN PEMBAHASAN}

\section{Analisis Kualitatif}

Berdasarkan analisis secara kualitatif dapat dikatakan bahwa komitmen pegawai sangat diperlukan dalam disiplin kerja dan untuk dapat dijadikan pedoman, referensi, petunjuk tentang apa yang harus dilakukan oleh pegawai. Disamping itu komitmen pegawai juga dapat menjadi penilaian 
disiplin kerja di dalam mempromosikan jabatan.

Berdasarkan pengamatan secara langsung diketahui bahwa secara umum pegawai PT Kereta Api Indonesia (Persero) Tanjung Karang telah mencapai sasaran kerja yang ditetapkan, dan dapat menyelesaikan pekerjaan atau tugasnya dengan baik, walaupun masih ada sebagian kecil pegawai yang tidak menyelesaikan tugasnya dengan tepat waktu. Olehnya itu diharapkan para pegawai dapat menyelesaikan tugas atau pekerjaannya dengan tepat waktu sebagai bentuk tanggung jawab terhadap tugas dan fungsi yang harus mereka kerjakan. Karena jika seluruh tugas dapat diselesaikan sesuai waktu yang ditentukan, maka akan membantu dalam meningkatkan kinerja dan pencapaian target kerja pegawai dapat lebih optimal.

\section{Analisis Kuantitatif}

Setelah dilakukan uji validitas Komitmen pegawai (X) diketahui bahwa 20 butir item pertanyaan di atas maka dapat dinyatakan 20 butir item valid karena mimiliki nilai corrected item-total correlation $>0.261$. Sedangkan variabel Disiplin kerja (Y) item pernyataan sebanyak 20 butir dari ke-20 penyataan tersebut dinyatakan instramen valid semua karena memiliki nilai corrected item-total correlation $>0.261$.

Berdasarkan uji reliabilitas kuisioner menunjukkan bahwa Cronbach Alpha untuk variabel komitmen memiliki nilai $0.906>0.60$ dan untuk variabel Disiplin kerja memiliki nilai $0.913>0.60$, berdasarkan hasil tersebut maka semua instrument variabel dalam penelitian ini adalah reliabel (konsisten) ini dikarenenakan nilai Cronbach Alpha > 0.60 .

Uji determinasi digunakan untuk mengetahui seberap jauh kemampuan model dalam menerangkan variasi variabel terikat (Disiplin kerja ). Hasil dari koefisien determinasi ( $R$ Square) sebesar 0.979 atau secara statistik 97.9\% Disiplin kerja PT Kereta Api Indonesia (Persero) Tanjung Karang dipengaruhi oleh komitmen pegawai. Sedangkan sisanya (100\%97.9.6\% $)=2.1 \%$ PT Kereta Api Indonesia (Persero) Tanjung Karang dipengaruhi oleh faktor-faktor lain selain variabel bebas yang sedang teliti.

Berdasarkan perhitungan diperoleh koefisien regresi sebesar 28.831 dan konstanta sebesar 3.412, maka dapat digambarkan bentuk hubungan variabel komitmen pegawai dengan Disiplin kerja dalam bentuk persamaan regersi $\mathrm{Y}=28.831$ $+3.412 \mathrm{X}$ ini berarti bahwa jika komitmen pegawai meningkat sebesar 1 poin maka Disiplin kerja akan meningkat sebesar 28.831 poin pada konstanta 3.412 . Sehingga dengan kata lain bahwa semakin baik komitmen pegawai seorang pegawai PT Kereta Api Indonesia (Persero) Tanjung Karang maka Disiplin kerja akan semakin tinggi sehingga berdampak kepada kemajuan dan program kerja yang akan dikerjakan.

Uji $\mathrm{t}$ digunakan untuk menguji hipotesis secara parsial komitmen pegawai terhadap Disiplin kerja PT Kereta Api Indonesia (Persero) Tanjung Karang. Berdasarkan perhitungan diperoleh $t_{\text {hitung }}$ untuk komitmen pegawai sebesar 28.831 sedangkan $\mathrm{t}_{\text {tabel }}$ sebesar dengan $\mathrm{dk}$ (30-2 = 28) adalah 1.688 , jadi $t_{\text {hitung }} 28.831>t_{\text {tabel }}$ $0.05(\mathrm{dk} 28)=1.688$, sehingga dengan demikian $\mathrm{Ho} 2$ ditolak $\mathrm{Ha} 2$ diterima dapat disimpulkan bahwa memang terdapat pengaruh yang signifikan antara komitmen pegawai terhadap Disiplin kerja PT. Kereta Api Indonesia (Persero) Tanjung Karang. 


\section{KESIMPULAN DAN SARAN}

\section{Kesimpulan}

Berdasarkan hasil penelitian dapat disimpulkan bahwa hasil uji hipotesis yang dilakukan melalui analisis regresi linier sederhana diperoleh persamaan dimana $\mathrm{t}_{\text {hitung }}$ untuk Komitmen pegawai sebesar 28.831 sedangkan $t_{\text {tabel }}$ sebesar dengan $\mathrm{dk}$ (30-2 - 28) adalah 1.688, jadi thitung 28.831 $>\mathrm{t}_{\text {tabel }} 0.05(30-2=28)=1-688$, sehingga dapat diketahui bahwa komitmen pegawai berpengaruh positip signifikan terhadap disiplin kerja PT. Kereta Api Indonesia (Persero) Tanjung Karang, Sedangkan dari hasil nilai Koefesien Determinasi $(R$ Square) diperoleh nilai sebesar 0.979 atau secara statistik $97.9 \%$ disiplin kerja PT. Kereta Api Indonesia (Persero) Tanjung Karang dipengaruhi oleh komitmen pegawai.

\section{Saran}

Berdasarkan hasil kesimpulan di atas maka penulis memberikan rekomendasi kepada pihak terkait dengan tujuan pegawai PT. Kereta Api Indonesia (Persero) Tanjung Karang dapat menjadikan komitmen pegawai sebagai alat untuk menjalin hubungan yang sinergis didalam meningkatkan disiplin kerja pegawai PT. Kereta Api Indonesia (Persero) Tanjung Karang:

1. Pegawai PT. Kereta Api Indonesia (Persero) Tanjung Karang seyogianya menjadikan dirinya sebagai teladan di dalam pelaksanaan disiplin pegawai di dalam meningkatkan kualitas sumber daya manusia yang berhasil guna.

2. Setiap pegawai PT. Kereta Api Indonesia (Persero) Tanjung Karang hendaknya dapat memahami organiasi yang ada di PT. Kereta Api Indonesia
(Persero) Tanjung Karang guna menjalin hubungan kerja yang sinergis.

\section{DAFTAR PUSTAKA}

Arikunto, Suharsimi. 2011. Statistik dan Aplikasi. Jakarta: Penerbit Erlangga.

Hadi, Sutrisno. 2002. Metodologi Research. Jilid 3. Yogyakarta: Andi Offset.

Handoko, T. Hani. 2002. Manajemen Personalia dan Sumber Daya Manusia. Yogyakarta: BPFE.

Hasibuan, M.S.P. 2009. Organisasi dan Motivasi: Dasar Peningkatan Produktivitas. Jakarta: Penerbit Bumi Aksara.

Mangkunegara, Anwar Prabu. 2005. Manajemen Sumber Daya Manusia, Cetakan Pertama, Bandung: PT. Rafika Aditama.

Mohyi, A. 1996. Teori dan Perilaku Organisasi. Malang: UMM Pres.

Munandar. 2001. Psikologi Industri dan Organisasi. Jakarta: UI.

Nawawi, H. dan Hadari M. 2004. Kepemimpinan Yang Efektif. Yogyakarta: Gajah Mada Universitas Press.

Robbins, Stephen P. 2008. Perilaku Organisasi, Konsep Kontroversi, Aplikasi. Jilid 1 Edisi Bahasa Indonesia. Jakarta: Pren hall Indo.

Siagian, Sondang P. 2005. Kiat meningkatkan Produktivitas Kerja. Jakarta: Rineka Cipta. 
A. Choiri Febriansyah : Pengaruh Komitmen Pegawai Terhadap Disiplin Kerja Pada Pt. Kereta Api Indonesia (Persero) Tanjung Karang

Sugiyono. 2003. Metode Penelitian Administrasi. Bandung: CV. ALFABETA.

Umar, Nimran. 2004. Perilaku Organisasi, Cetakan Ketiga. Surabaya: CV. Citra Media. 